\title{
5- Türkçe öğretmeni adaylarının ilk okuma yazma öğretimi dersine yönelik görüşleri
}

\section{İrem BAYRAKTAR ${ }^{1}$}

APA: Bayraktar, İ. (2021). Türkçe öğretmeni adaylarının ilk okuma yazma öğretimi dersine yönelik görüşleri. RumeliDE Dil ve Edebiyat Araştırmaları Dergisi, (25), 71-84. DOI: $10.29000 /$ rumelide.1032368.

\section{$\ddot{O} \mathbf{z}$}

Eğitimin ilk basamağını oluşturan ilk okuma ve yazma insan hayatını doğrudan etkilemektedir. İlkokula başlayıncaya kadar okuma ve yazma bilmeyen çocuğun bu öğretimle birlikte sosyokültürel dünyasında önemli bir değişim meydana gelir. İlk okuma yazma öğretiminin niteliği de bu önem doğrultusunda şekillenir. Ancak çeşitli sebeplerden dolayı öğrencinin, ilkokul yllarında okuma yazma becerisi tam olarak gelişmeyebilir. Böylece ilkokul yllarında kazanılamayan bu beceri ortaokul dönemine taşınır. Bu durumda da, Türkçe öğretmenlerinden okuma yazma bilmeyen ya da bu becerileri tam olarak gelişmemiş öğrencilere okuma ve yazma öğretmeleri beklenir. Türkçe öğretmenlerinin bu nedenle ilk okuma yazma esaslarını bilmeleri ve buna uygun öğretim programı düzenlemeleri gerekmektedir. Bu araştırmanın amacı, Türkçe öğretmeni adaylarının "İlk Okuma Yazma Öğretimi” dersine yönelik görüşlerini belirlemektir. Araştırmanın amacı doğrultusunda çalışma, nitel araştırma yöntemlerinden durum çalışması ile desenlenmiştir. Çalışma grubu olarak, Ondokuz Mayıs Üniversitesi Eğitim Fakültesi Türkçe Eğitimi Bölümü 2020-2021 eğitim-öğretim döneminde üçüncü sinıfta öğrenim gören 42 Türkçe öğretmeni adayı amaçlı örnekleme yöntemi ile seçilmiştir. Bu çalışmada, Türkçe öğretmeni adaylarının İlk Okuma Yazma Öğretimi dersine yönelik görüşleri 6 sorudan oluşan yapılandırılmış görüşme formu ile toplanmıştır. İlk Okuma Yazma Öğretimi Dersine Yönelik Görüşme Formu’nda Türkçe öğretmeni adaylarının derse yönelik sorulan sorulara verdikleri cevaplar üzerinde içerik analizi yöntemi uygulanmıştır. Bu doğrultuda elde edilen verilerin analizi neticesinde ilk okuma yazma teması altında ortaya çıkan kategoriler, kodlar ve öğretmen adaylarının görüşleri tablolar ve doğrudan alıntılar hâlinde sunulmuştur. Çalışma sonucunda, Alan Eğitimi Seçmeli ders grubunda yer alan İlk Okuma Yazma Öğretimi dersinin lisans müfredatında zorunlu ders grubunda olması gerektiği öğretmen adaylarının görüşlerinden hareketle ortaya çıkmıştır.

Anahtar kelimeler: İlk okuma yazma, Türkçe öğretmeni adayları, mesleki yeterlilik

\section{The opinions of Turkish teacher candidates on the first literacy teaching class}

\begin{abstract}
The first literacy, which is the first step of education, directly affects human life. With this teaching, a significant change occurs in the socio-cultural world of the child who cannot read and write until the child starts primary school. The quality of primary literacy teaching is also shaped in line with this importance. However, the student's reading and writing skills may not develop fully during the primary school years for various reasons. Thus, this skill, which cannot be acquired in primary school years, is carried over to the secondary school period. In this case, Turkish teachers are expected to
\end{abstract}

Dr. Öğr. Üyesi, Ondokuz Mayıs Üniversitesi, Eğitim Fakültesi, Türkçe ve Sosyal Bilimler Eğitimi, Türkçe Eğitimi ABD (Samsun, Türkiye), urhanirem@gmail.com, ORCID ID: . oooo-0o02-3789-6731 [Araştırma makalesi, Makale kayt tarihi: 18.10.2021-kabul tarihi: 20.11.2021; DOI: 10.29000/rumelide.1032368]

Adres | Address

RumeliDE Dil ve Edebiyat Araşturmaları Dergisi Osmanağa Mahallesi, Mürver Çiçeği Sokak, No:14/8 Kadıköy - İSTANBUL / TÜRKIYE 34714 e-posta: editor@rumelide.com tel: +90 $5057958124,+902167730616$

RumeliDE Journal of Language and Literature Studies Osmanağa Mahallesi, Mürver Çiçeği Sokak, No:14/8

Kadıköy - ISTANBUL / TURKEY 34714

e-mail: editor@rumelide.com,

phone: +90 505 7958124, +90 2167730616 
The opinions of Turkish teacher candidates on the first literacy teaching class / İ. Bayraktar (pp. 71-84)

teach reading and writing to students who are illiterate or who have not fully developed these skills. Hence, Turkish teachers need to know the basics of first literacy and organize a curriculum accordingly. The aim of this research is to determine the opinions of Turkish teacher candidates about the "First Literacy Teaching" course. In line with the purpose of the research, the study was designed with a case study, one of the qualitative research methods. 42 Turkish teacher candidates studying in the third grade of Department of Turkish Education, Faculty of Education Ondokuz Mayıs University in the 2020-2021 academic year were selected as the study group with purposive sampling method. In this study, the opinions of Turkish teacher candidates about the First Literacy Teaching course were collected with a structured interview form consisting of 6 questions. Content analysis method was applied on the answers given by Turkish teacher candidates to the questions asked about the lesson in the Interview Form for the First Literacy Teaching Lesson. Accordingly, as a consequence of the analysis of the data obtained, the categories, codes and opinions of the teacher candidates that emerged under the first literacy theme were presented in tables and direct quotations. As a result of the study, it was revealed that the first Literacy Teaching course in the Field Education Elective course group should be included in the compulsory course group in the undergraduate curriculum based on the opinions of candidate teachers.

Keywords: First literacy, Turkish teacher candidate, professional competence

\section{Giriş}

Temel eğitime başlayan her öğrenci ilk okuma yazma öğretimiyle karşı karşıya kalır. Dinleme ve konuşma becerisi okul öncesi dönemde çocukta belirli bir düzeyde gelişmişken okuma ve yazma becerisi çocuğun ilkokula başlamasıyla edinilir. İlk okuma yazma öğretimi, okumanın ve yazmanın öğrenildiği bir süreci kapsar. Bu öğretimin temel amacı öğrencinin gerek eğitim hayatını gerekse okul dışındaki hayatını idame ettirebilmesini sağlamaktır. Dolayısıyla eğitimin ilk basamağını oluşturan bu beceri doğrudan insan hayatını etkilemektedir. İlkokula başlayıncaya kadar okuma ve yazma bilmeyen çocuğun bu öğretimle birlikte sosyokültürel dünyasında önemli bir değişim meydana gelir. Eğitimin temelini oluşturan ilk okuma yazma öğretiminin niteliği de bu önem doğrultusunda şekillenir. İlk okuma yazma öğretiminin niteliği öğrencinin;

Sosyal bir varlık olarak ailesi ve çevresiyle kurduğu iletişimi,

Eğitim hayatının devam etmesiyle akademik başarısını,

Okul dışında da var olan hayata yüklediği anlamı,

Zihinsel becerilerinin gelişimini etkiler.

İlk okuma yazma öğretimi dilin anlama ve anlatma yönüne işaret eden okuma ve yazma becerilerinin birleştirilerek öğretilmesidir. Alfabedeki her harfin önce seslendirilmesi ve okunması ardından yazdırılmasıyla başlayan bu süreçte hece, kelime ve cümle oluşturma öğretilmektedir. Eş zamanlı şekilde okuma becerisinin yazmayı; yazma becerisinin okumayı desteklediği bu süreçte anlama üzerinde de durulmaktadır (Güneş, 2019, s. 26). Öğrencilerin bu dönemde edinecekleri ilk okuma yazma beceri ve alışkanlıkları eğitim hayatlarını ve başarılarını doğrudan etkileyecektir. Bu dönemde kazanılan temel beceri ve alışkanlıklar bütün dersler için önem taşımaktadır (Göçer, 2019, s. 11). Ancak çeşitli sebeplerden dolayı öğrencinin, ilkokul yllarında okuma ve yazma becerisi tam olarak gelişmeyebilir. İlgili alanda yapılan araştırmalar da ilkokulda karşılaşılan okuma ve yazma öğretimi sorunlarının sebeplerini ortaya koymuştur (Babayiğit ve Erkuş, 2017; Karayel, 2017; Gönül ve Arslan, 2018; Çetinkaya, 2021; Başar ve Gürbüz, 2020) Bu araştırmalara göre;

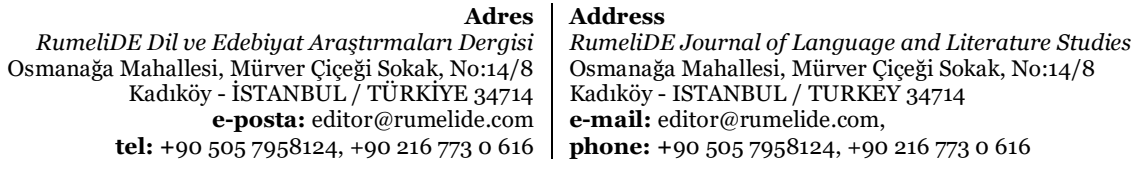


Öğrencilerin hazırbulunuşluk düzeyinin yetersiz olması,

Sinıfların kalabalık olması,

Okul tatillerinin uzun olması dolayısıyla öğrencinin okumayı ve yazmayı unutması,

Velilerin ilk okuma yazma öğretim yöntemini bilmemelerinden dolayı yanlış öğrenmelere sebebiyet vermesi,

Derslerde kullanılması gereken materyallerinin eksikliği,

Öğrencinin birleştirilmiş sınıfta okuması,

Okul olgunluğuna ulaşmamış öğrencinin ilkokula başlaması,

Velilerin ilgisizliği,

Motivasyon düşüklüğü,

Öğretim programının yetersizliği gibi pek çok etken öğrencilerin okuma ve yazma becerilerinin istenilen düzeyde gelişmemesine neden olabilmektedir.

Böylece ilkokul yıllarında tam olarak kazanılamayan bu beceri ortaokul dönemine taşınır. Bu durumda da, Türkçe öğretmenlerinden okuma ve yazma bilmeyen ya da bu becerileri tam olarak gelişmemiş öğrencilere okuma ve yazma öğretmeleri beklenmektedir. Türkçe öğretmenlerinin bu nedenle ilk okuma yazma esaslarını bilmeleri ve buna uygun öğretim programı düzenlemeleri gerekmektedir. Türkçe öğretmenleri bu öğretimi yapabilmek için Türkçe Dersi Öğretim Programı’na başvurabilir.

2005 yılından itibaren hazırlanan Türkçe Dersi Öğretim Programları öğrencinin birikim, beceri ve gelişimi göz önünde bulundurularak öğrenciyi merkeze alan bir yaklaşımla hazırlanmıştır. 2015 yllından itibaren hazırlanan programlarda ise öğrenme alanları, 1. sınıftan 8. sinıfa kadar bir bütün olarak aşamalı bir şekilde yapılandırılmıştır. Bu nedenle 2015, 2018 ve 2019 Türkçe Dersi Öğretim Programları'nda, ilk okuma yazma öğretimi ile ilgili esaslar da yer almıştır. 2019 Türkçe Dersi Öğretim Programı'nda (s. 10), Türkçeyi doğru, güzel ve etkili kullanmaya dönük becerilerin kazandırıldığı bir ilk okuma yazma öğretimi amaçlandığı belirtilmiştir. İlk okuma yazma öğretiminin düşünme, anlama, sıralama, sınıflama, sorgulama, ilişki kurma, analiz sentez yapma ve değerlendirme gibi zihinsel becerilerin geliştirilmesinde önemli bir işlevi olduğu bu nedenle ilk okuma yazma öğretiminin temel düzeyde okuma ve yazma becerileri ile sınırlı tutulmadığı belirtilmiştir. Bu açıklamalardan hareketle Türkçe öğretmeni, programın ilk okuma yazma süreciyle ilgili olarak sunduğu esasları takip edebilir. Ancak ilk okuma yazma öğretimi zor bir süreçtir. Türkçe öğretmeninin ilk okuma yazmayı öğrenememiş bir öğrenciyle karşılaştığında ne yapacağını bilmesi çok önemlidir. Bu durumda da Türkçe öğretmeninin lisans öğreniminde henüz öğretmen adayıyken bu duruma hazırlanması için bir öğretim görmesi gerekir.

2018 yllında yenilenen Türkçe Öğretmenliği lisans programlarındaki dersler; Öğretmenlik Meslek Bilgisi (MB), Alan Eğitimi (AE) ve Genel Kültür (GK) dersleri olmak üzere üç gruptan oluşmaktadır. Alan Eğitimi Seçmeli Dersleri programda: Anlam Bilimi, Dil Edinimi, Eleştirel Okuma, İki Dilli Türk Çocuklarma Türkçe Öğretimi, İlk Okuma Yazma Öğretimi, Kelime Öğretimi, Medya Okuryazarlı̆̆, Ses Eğitimi ve Diksiyon, Sinıf İçi Öğrenmelerin Değerlendirilmesi, Türkçe Ders Kitabı İncelemesi, Türkçe Öğretimi Tarihi, Türkçe Öğretiminde Materyal Tasartmı, Türkçe Öğretiminde Sinav Hazırlama ve Değerlendirme, Yaratıcı Yazma şeklinde belirlenmiştir. 2018 yllından önce uygulanan Türkçe Öğretmenliği lisans programında (2006) bu ders seçmeli ya da zorunlu ders kategorisinde yer almamıştır. Seçmeli ders grubunda dâhi olsa İlk Okuma Yazma Öğretimi dersi 2018 Türkçe Öğretmenliği lisans programında yer almıştır.

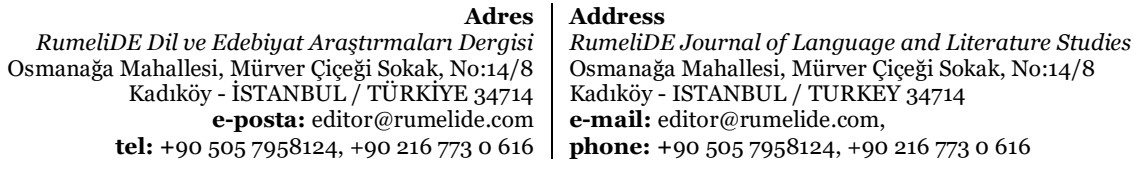


İlk Okuma Yazma Öğretimi dersi ile ilgili Türkçe Öğretmenliği Lisans Programı’nda: “Türkiye'de ilk okuma yazma öğretiminin geçmişi; ilk okuma yazma öğretim yöntemleri (Alfabe yöntemi, hece yöntemi, öykü-cümle yöntemi vb.); Ses Temelli Cümle Yöntemi, uygulama aşamaları; alternatif uygulamalar; ortaokul düzeyinde okuma yazma sorunları ve ileri sınıflarda okuma yazma öğretimi.” olmak üzere yapılacak öğretimin içeriği belirlenmiştir. Bu açıklamaya göre, ortaokul veya daha ileri düzeylerde okuma yazma konusunda sorun yaşayan öğrenciler olabileceği ve bu öğrencilere yönelik okuma yazma öğretimi yapılabileceği anlaşılmaktadır. İlk Okuma Yazma Öğretimi dersinin bu ihtiyaca yönelik programda yer bulduğu aşikârdır.

Programda zorunlu ders kategorisinde yer almayan İlk Okuma Yazma Öğretimi dersi Alan Eğitimi Seçmeli ders grubunda yer alan 14 dersten biridir. Türkçe Öğretmenliği lisans programında öğretmen adaylarının 6 Alan Eğitimi Seçmeli Ders alması gerektiğinden bu ders, dersi okutmak isteyen öğretim üyesi tarafından açılmaktadır. Dersi alan Türkçe öğretmeni adayları okuma ve yazma konusunda sıkıntı yaşayan öğrencilerle karşılaştıklarında ne yapacaklarını bilecekler ve öğrenciye uygun bir öğretim programı oluşturabileceklerdir. Bu noktada problem, dersi lisans öğreniminde almayan Türkçe öğretmenleri açısından ortaya çıkmaktadır. Okuma ve yazma bilmeyen ya da bu becerileri istenilen düzeyde gelişmemiş öğrencilerle karşılaştıklarında sorun yaşayacaklarıdır. Bu nedenle, okuma ve yazma becerilerinin hayati öneminden dolayı öğretmen yeterliliğin arttırılması amacıyla İlk Okuma Yazma Öğretimi dersinin Türkçe Öğretmenliği Lisans Programı'nda zorunlu ders olması gerektiği düşünülmektedir.

Bu doğrultuda araştırmanın amacı Türkçe öğretmeni adaylarının “illk Okuma Yazma Öğretimi” dersine yönelik görüşlerini belirlemektir. Aynı zamanda araştırma sonuçlarından hareketle bu dersin müfredat programındaki yeri ve içeriği ile ilgili veriler elde edilebilmesi amaçlanmaktadır.

\section{Yöntem}

\section{Araştırmanın modeli}

Araştırmanın amacı doğrultusunda çalışma, nitel araştırma yöntemlerinden durum çalışması ile desenlenmiştir. Durum çalışması, birey, kurum, grup, ortam, olay, süreç gibi etkenlerin bir duruma ilişkin sonuçlarının bütüncül bir yaklaşımla ortaya konulduğu araştırma desenidir. Bu araştırma deseninde bir duruma ilişkin etkenlerin ilgili durumu nasıl etkiledikleri ve ilgili durumdan nasıl etkilendikleri üzerinde durulur (Yıldırım ve Şimşek, 2018, s. 73).

Duruma ilişkin derinlemesine bir analiz sunmaya imkân sağlayan bu desende gözlem, görüşme, doküman ve birçok materyal aracilığıyla veri toplanabilir (Creswell, 2021, s.100). Çalışmada, Türkçe öğretmeni adaylarının İlk Okuma Yazma Öğretimi dersine yönelik görüşleri ve bu dersi aldıktan sonra bakış açılarında meydana gelen değişimleri anlamak için bu desen kullanılmıştır.

\section{Çalışma grubu}

$\mathrm{Bu}$ araştırmanın çalışma grubunu belirlemek için örneklem seçme yöntemlerinden amaçlı örnekleme kullanılmıştır. Amaçlı örnekleme araştırmacının, nitel araştırma yapmak için ortaya konulmak istenen problem, süreç ve olayla ilgili farklı bakış açılarını ortaya koyacak çalışma grubunu seçmesi anlamına gelir (Creswell, 2021, s. 294). Bu çalışma için Ondokuz Mayıs Üniversitesi Eğitim Fakültesi Türkçe Eğitimi Bölümü 2020-2021 eğitim-öğretim döneminde üçüncü sinıfta öğrenim gören 42 Türkçe öğretmeni adayı amaçlı örnekleme yöntemi ile seçilmiştir. Bu grup, 2018 ylında güncellenen Türkçe

\footnotetext{
\begin{tabular}{r|l} 
Adres & Address \\
RumeliDE Dil ve Edebiyat Araştırmaları Dergisi & RumeliDE Journal of Language and Literature Studies
\end{tabular} Osmanağa Mahallesi, Mürver Çiçeği Sokkak, No:14/8 $\quad$ Osmanağa Mahallesi, Mürver Çiçeği Sokak, No:14/8 Kadıköy - ÍSTANBUL / TÜRKIYE 34714 Kadıköy - ISTANBUL / TURKEY 34714 e-posta: editor@rumelide.com e-mail: editor@rumelide.com, tel: +90 505 7958124, +90 2167730616 phone: +90 505 7958124, +90 2167730616
} 
Öğretmenliği lisans programına tabi olan ve Alan Eğitimi seçmeli ders grubunda yer alan "İlk Okuma Yazma Öğretimi” dersini alan öğretmen adaylarından oluştuğu için seçilmiştir.

\section{Veri toplama aracı}

Bu çalışmada, Türkçe öğretmeni adaylarının İlk Okuma Yazma Öğretimi dersine yönelik görüşleri yapılandırılmış görüşme formu ile toplanmıştır. Yapılandırılmış görüşme formu; sınıf öğretmeni, Türkçe öğretmeni ve Türkçe eğitimi alan uzmanından oluşan 3 uzman görüşü alınarak hazırlanmıştır. Uzman görüşleri doğrultusunda görüşme formundan bir soru başka bir sorunun tekrarı olduğu gerekçesiyle çıarılmış ve form içerik, dil ve anlatım açısından yeniden düzenlenerek veri toplamaya hazır hâle getirilmiştir. Görüşme formunda yer alan 4. sorudaki parantez içi açıklama öğretmen adaylarının İlk Okuma Yazma Öğretimi dersini zorunlu ders grubu kategorisinde biliyor olmasından dolayı eklenmiştir. Görüşme formunun son hâli olan 6 soru aşağıda belirtilmiştir:

1. İlk Okuma Yazma Öğretimi dersinin içinde barındırdığı kavramlara göre bu dersi nasıl tanımlarsınız?

2. İlk Okuma Yazma Öğretimi dersine başlamadan önce dersle ilgili görüşleriniz nelerdi?

3. İlk Okuma Yazma Öğretimi dersini aldıktan sonra bu derse yönelik bakış açınızda ne gibi değişiklikler olmuştur?

4. İlk Okuma Yazma Öğretimi dersinin Seçmeli ders grubunda olması ile ilgili görüşleriniz nelerdir? (Bu dersi öğretim üyesi Alan Eğitimi Seçmeli Ders grubundan seçerek açmıştır.)

5. İlk Okuma Yazma Öğretimi dersinde edindiğiniz bilgilerin öğretmenlik yaşamınıza katkı sağlayacağını düşünüyor musunuz? Açıklayınız.

6. İlk Okuma Yazma Öğretimi dersinin içeriğine yönelik önerileriniz nelerdir?

\section{Verilerin toplanması}

Araştırma verileri gerekli izinler dâhilinde 2020-2021 eğitim-öğretim yllının güz döneminde Alan Eğitimi Seçmeli İlk Okuma Yazma Öğretimi dersinin tamamlandığı hafta toplanmıştır. İçinde bulunulan pandemi koşulları nedeniyle Google Classroom Meet bağlantısı kullanılarak öğretmen adayları çalışma hakkında bilgilendirilmiş ve görüşme formu öğretmen adaylarıyla paylaşılarak verilerin alınması sağlanmıştır.

\section{Verilerin analizi}

İlk Okuma Yazma Öğretimi Dersine Yönelik Görüşme Formu’nda Türkçe öğretmeni adaylarının derse yönelik sorulan sorulara verdikleri cevaplar üzerinde içerik analizi yöntemi uygulanmıştır. İçerik analizi, çalışmada elde edilen verilerin tanımlanmasını ve incelenmesini içerir. Bu analizde amaç, birbirine benzeyen verileri okuyucunun anlayacă̆ şekilde bir araya getirerek yorumlamaktır. İçerik analizinde nitel araştırma verileri aşağıda belirtilen aşamalardan oluşur (Yıldırım ve Şimşek, 2018, s. 243-251):

1) Verilerin kodlanması: Araştırmacının çalışmada elde ettiği verileri, anlamlı bölümlere ayırması ve her bölümün ifade ettiği kavramları tespit etmesi sürecidir. Bu kavramsal kodlama bölümleri tanımlayıcı bir ya da birkaç sözcükten oluşur.

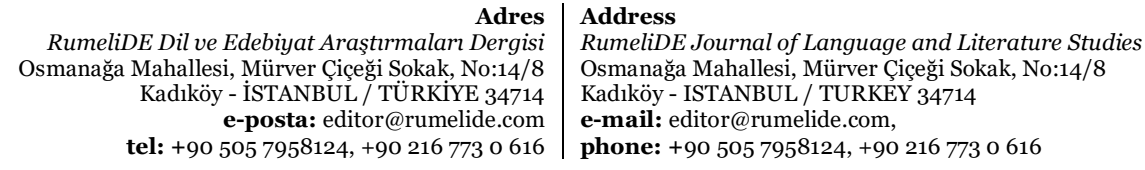


2) Temaların bulunması: Kodların belirlenmesinden sonra bu kodların ortak yönlerinin belirli kategoriler altında toplaması üzere temalar tespit edilir. Tematik kodlama da denen bu işlem verilerin kodlar aracılı̆̆ıla kategorize edilmesi anlamına gelir.

3) Kodların ve temaların düzenlenmesi: Okuyucunun anlayabileceği ve nesnel bir şekilde verilerin tanımlanması, açıklanması ve sunulması aşamasıdır.

4)Bulguların tanımlanması ve yorumlanması: Tanımlanan ve sunulan bulguların araştırmacı tarafından yorumlandığı ve araştırmacının birtakım sonuçlara ulaştığı aşamadır.

Bu çalışmada, İlk Okuma Yazma Öğretimi Dersine Yönelik Görüşme Formu’ndan elde edilen veriler araştırmacı tarafından kodlanarak kategoriler belirlenmiştir. Kodlar ve kategoriler belirlendikten sonra üç alan uzmanından alınan görüş neticesinde kodlara ve kategorilere son şekli verilerek okuyucu için hazır hâle getirilmiştir. İlk Okuma Yazma Öğretimi teması altında belirlenen altı kategori ve ifade ettiği kodlar frekans ve yüzde hesaplamaları ile birlikte tablolar biçiminde ifade edilmiştir. Türkçe öğretmeni adaylarının İlk Okuma Yazma Öğretimi dersine yönelik görüşleri, çalışmada elde edilen sonuçların geçerlik ve güvenirliğine ilişkin önemli bir gösterge olduğundan (Yıldırım ve Şimşek, 2018, s. 48), doğrudan alıntı şeklinde bulgular bölümünde sunulmuştur.

\section{Bulgular}

Araştırmanın amacı doğrulusunda elde edilen verilerin analizi neticesinde İlk okuma yazma teması altında ortaya çıkan kategoriler, kodlar ve öğretmen adaylarının görüşleri bu bölümde sunulmuştur. Öğretmen adaylarının görüşleri birden fazla kodu işaret edebildiğinden görüş sayısı katılımcı sayısından fazla olabilmektedir.

\section{İlk Okuma Yazma Öğretimi dersinin içinde barındırdığı kavramlara göre bu dersi nasıl tanımlarsiniz?}

Tablo 1. "İlk Okuma Yazma Öğretimi dersinin içinde barındırdığı kavramlara göre bu dersi nasıl tanımlarsınız?” sorusuna yönelik katılımcı görüşleri

\begin{tabular}{llll}
\hline Kategoriler & Kodlar & $\mathbf{f}$ & \% \\
\hline \multirow{2}{*}{ İlk okuma yazma öğretimi tanımı } & Temel eğitim & 25 & 59,52 \\
\cline { 2 - 4 } & Ses esaslı ilk okuma yazma & 13 & 30,95 \\
\cline { 2 - 4 } & Hayatilik & 10 & 23,80 \\
\hline
\end{tabular}

Tablo 1 incelendiğinde öğretmen adaylarının İlk Okuma Yazma Öğretimi dersini en çok temel eğitim kavramıyla tanımladıkları görülmektedir. Bu koda yerleştirilen öğretmen adayı görüşlerinden bazıları şöyledir:

Ö15: “İlk okuma yazma öğretimi temel eğitimin başlangıcında öğrencilerin önceden mevcut olan dil becerilerine okuma ve yazma becerilerinin de kazandırlmasıdır."

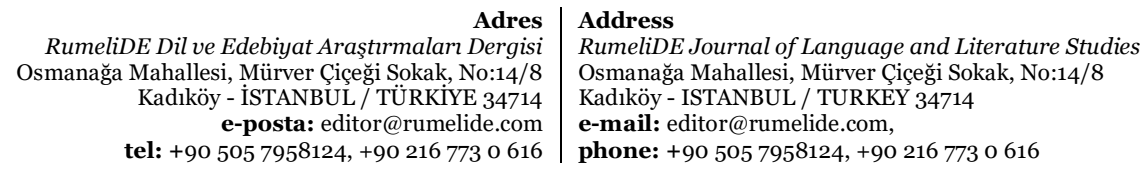


Ö27: "İlk okuma yazma öğretimi dersi, erken çocukluk döneminde başlayan dil becerilerine okuma ve yazma becerilerinin de kazandırılmasını sağlayan temel eğitimin birinci basamağında sürdürülen dil öğretimi sürecidir...”

Ö41: "İlk okuma yazma dersi tüm eğitimin temelini oluşturur. Yaş grubuna göre belirli harf gruplarından başlayarak, öğrencilere kapalı açık hece, kelime ve cümle kurma yetisini kazandıran aynı zamanda diğer derslerin de temeli olan bir öğretidir...”

Öğretmen adaylarının İlk Okuma Yazma Öğretimi dersini tanımlarken ses esaslı ilk okuma yazma kavramını kullandıkları görülmektedir:

Ö41: ...Ses temelli cümle yöntemi aşamaları dikkate alnarak bir öğretim gerçekleştirilir...”

Ö31: “Okumayı öğrenecek bireyin, okumanın temel düzeyinden başlayarak, ses temelli okuma yöntemi ile bireyin dik temel harflerle yazma kabiliyetini geliştiren bir süreçtir.”

Öğretmen adayları İlk Okuma Yazma Öğretimi dersini tanımlarken ilk okuma yazma öğrenmenin hayatilik boyutuna da dikkati çekmişlerdir:

Ö11: “İlk okuma yazma dersi temel düzeyde sadece okuma ve yazmaya dayah bir ders değildir... Çünkü çocuğun ilk okuma ve yazma öğrenimi öğrencinin hayatı boyunca kullanacaktır. Bu nedenle ilk ögrrenmelerin doğru bir şeklide oluşturulup devam ettirilmesi hayati önem taşımaktadır...”

Ö34: “İlk okuma ve yazma eğitimi dersinin amacı öğrencilere hayatı boyunca kullanacağı okuma ve yazma becerilerini kazandırmaktır...”

Ö39: “İlk okuma yazma öğretiminin, öğrencinin hayatı boyunca alacă̆ı tüm eğitimin temel taşı olduğu görüşündeyim...”

\section{İlk Okuma Yazma Öğretimi dersine başlamadan önce dersle ilgili görüşleriniz nelerdi?}

Tablo 2. "İlk Okuma Yazma öğretimi dersine başlamadan önce dersle ilgili görüşleriniz nelerdi?” sorusuna yönelik katılımcı görüşleri

\begin{tabular}{llll}
\hline Kategoriler & Kodlar & $\mathbf{f}$ & \% \\
\hline & Ön yargı & 26 & 61,90 \\
\cline { 2 - 3 } $\begin{array}{l}\text { Dersten } \\
\text { ocnceki bakışı }\end{array}$ & $\begin{array}{l}\text { Alana } \\
\text { uygunluk }\end{array}$ & 20 & 47,61 \\
\cline { 2 - 3 } & Merak & 10 & 23,80 \\
\hline & Belirsizlik & 8 & 19,04 \\
\hline
\end{tabular}

Tablo 2 incelendiğinde öğretmen adaylarının İlk Okuma Yazma Öğretimi dersini almadan önce en çok ön yargılı bir tutuma sahip oldukları ve dersin alana uygunluğunu sorguladıkları görülmektedir. Bu kodlara yerleştirilen öğretmen adaylarının görüşleri şöyledir:

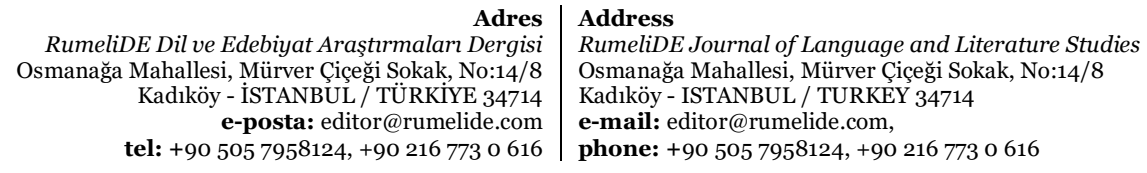


Ö3: "Ortaokula gelen bir öğrencinin okuma-yazma öğrenme anlamında tamamen ya da kısmen öğrenmemesinin mümkün olmayacağın olsa bile benim sorunum olmadığını, o öğrenciye eğitim veren simı öğretmenlerinin sorumluluğunda olduğunu düşünüyordum.”

Ö27: “İlk okuma yazma öğretimi dersine başlamadan önce aslında dersle ilgili olarak biraz önyargıda bulundum. Bu dersin daha çok sinı öğretmenlerine uygun olduğunu düşünüyordum. Çünkü Türkçe öğretmenleri ortaokullara girmekte ve ortaokul öğrencileri okuma ve yazmayı biliyor diye düşünüp bizim bu dersi almamıza ne gerek var demiştim...”

Ö8: "Dersi ilk ders seçme ekraninda gördüğümde biz sinıf öğretmenliği okumuyoruz Türkçe öğretmenliği okuyoruz diye düşünmüş̧üm. Ön yargıyla yaklaşmıştım...”

Ö18: "Bu dersin neden bizim bölümde olduğu konusunda aklmda ilk başta soru işareti vardı. Çünkü sinı öğretmenliği bölümü dersi olarak düşünüyordum.”

Öğretmen adaylarının İlk Okuma Yazma Öğretimi dersini almadan önce derse yönelik merak ve belirsizlik duygusu taşıdıkları da görülmektedir:

Ö3: “Açıkçası bu derse başlamadan önce bu dersi neden görüyoruz, bu ders bize ne için gerekli olacak diye düşündüm. Çünkü ortaokul Türkçe öğretmeni adayıyım ve ortaokul öğrencileri için eğitim alyorum...”

Ö10: "Ben bu senenin başında dersleri seçerken bu ders neden var diye düşünmüştüm. Çünkü bize zaten okuma-yazmayı bilmeyen gelmez, öğrenci okuma-yazmayı bilmeden ortaokula kadar nasıl gelsin ki demiştim...”

Ö14: “Biz, ortaokul öğretmeni adayları için ne ifade edeceğinden tam olarak emin değildim.”

\section{İlk Okuma Yazma Öğretimi dersini aldıktan sonra bu derse yönelik bakış açınızda ne gibi değişiklikler olmuştur?}

Tablo 3. "İlk Okuma Yazma Öğretimi dersini aldıktan sonra bu derse yönelik bakış açınızda ne gibi değişiklikler olmuştur?” sorusuna yönelik katılımcı görüşleri

\begin{tabular}{llll}
\hline Kategoriler & Kodlar & $\mathbf{f}$ & \% \\
\hline \multirow{3}{*}{ Dersten sonraki bakış açısı } & Dersin gerekliliği & 35 & 83,33 \\
\cline { 2 - 4 } & Dersin önemi & 32 & 76,19 \\
\cline { 2 - 4 } & Ö̆̆grenciye katkısı & 26 & 61,90 \\
\cline { 2 - 4 } & Hatırlama ve bakış açısını değiştirme & 10 & 23,80 \\
\hline
\end{tabular}

Tablo 3 incelendiğinde öğretmen adaylarının İlk Okuma Yazma Öğretimi dersine yönelik görüşlerinin dersi almadan önceki görüşlerine göre değiştiği; dersin gerekliliğine, önemine ve öğrenciye olan katkısına vurgu yaptıkları görülmektedir. Bu kodlarda olan öğretmen adaylarının görüşleri şöyledir:

Ö9: “...Dersi almaya başladıktan sonra bu eğitimi Türkçe öğretmenliği bölümü öğrencilerinin de almalarmın ne kadar gerekli olduğunun farkına vardım. İlkokulda okuma-yazma becerileri gelişemeyen öğrencilerin, gelişmeyen becerileri ile ortaokula devam ettikleri bilinmektedir. Genellikle

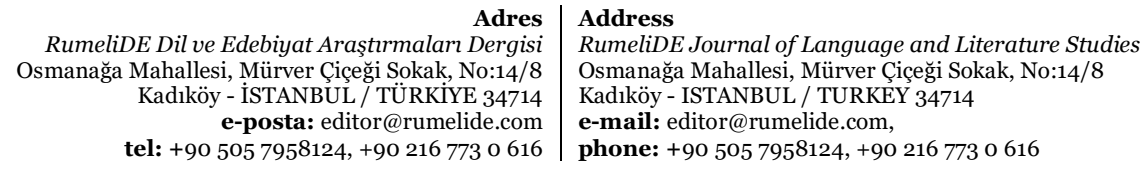


bu öğrencilerle Türkçe öğretmenleri ilgilenmektedirler. İşte bu öğrencilerle nasıl ilgilenilmesi gerektiğini Türkçe öğretmeninin çok iyi bilmesi gerekmektedir.”

Ö16: "Dersle birlikte anladım ki bu ders bizim için çok önemli bir dersmiş. Belki biz Türkçe öğretmen adayları olarak 5, 6, 7 ve 8.sinıflarn derslerine gireceğiz ama az da olsa illaki okuma yazmayı hâlâ tam öğrenememiş öğrenciler olacaktır ve biz bu öğrencilerle mutlaka karşllaşacağız. Bu ders sayesinde bu durumlarda nasıl hareket edeceğimizi, nerden başlayacağımızı, ne yapacağımızı öğrenmiş olduk.”

Ö17: “ỉlk gördüğümde bu kadar önemli olacağını tahmin etmemekle birlikte, dersi işledikçe gerçekten önemli ve öğrenilmesi gereken bir ders olduğunu anladım. Çünkü ilk okuma-yazma öğretiminde hangi yaklaşımın kullanılmakta olduğunu, bu yaklaşımın neden ve nasıl öğretilmesi gerektiğini, öğretmenlik hayatımda ne gibi durumlarla karşılaşabileceğimi ve bunlarm tespiti, çözümü için bana düşen görevlerin neler olduğunu bu dersle öğrendim.”

Ö22: “İlk okuma yazma dersinin dersi almadan önceki fikirlerime nazaran hem öğretmen hem öğrenci için hem içerik hem ders bakımından ne kadar mühim olduğunu ve gerekli olması gerektiğini kavradım. Çünkü okuma ve yazma en temel becerilerdendir ve bunu her öğrencinin iyi bir şekilde kavraması lazımdir bunun içinde öğretmen ve öğretmen adaylartnın bu dersi iyi bir şekilde anlayıp, ileride mesleğe başlayınca o bilgiler ve kazanımlar doğrultusunda öğrencilere bilgi ve kazanım aktarması yapmahdır."

İlk Okuma Yazma Öğretimi dersi ile birlikte öğretmen adayları geçmiş yaşantılarından yola çıkarak dersle ilgili bakış açılarını değiştirdikleri görüşlerini iletmişlerdir:

Ö8: “...Illkokul ve ortaokul yıllarımı düşündüğümde bizim de sinıfımızda böyle bir öğrencinin olduğunu hatırladım. Bu öğrenciler, öğretmenler tarafindan bu sene öğrenemedi seneye öğrenir diyerek sorumsuzca ortaokula kadar sınf atlatılmış, ortaokulda ise bu saatten sonra geri kalmasin diyerek simı atlatılmaya devam etmiş oluyorlar. Okuma-yazmayı sökemeyen, arkadaşlarından geri kalan öğrencilere yardım etmemiz gerektiğinin bilincindeyim artık. Çünkü öğretmenlik kutsal bir meslektir...”

Ö13: "Bu dersi aldıktan sonra, artık daha fazla bilinçli olmaya başladım. Örneğin düşündüğümde benim kardeşimin sinıfinda da ortaokula gelmiş ve hala okuma, yazma bilmeyen öğrenciler vardı ve o zaman bunu hiç düşünmemiştim. Daha önce dikkatimi çekmemişti bu durum ancak şimdi düşündüğümde, ben o öğretmenlerin yerinde olsaydım ve bu becerileri öğrenciye vermem gerekseydi zor bir durum yaşardım. Öğrenciye öğretmeden önce, benim de ayrıca öğrenciye nasll öğretmem gerektiğini öğrenmem gerekecekti. Bu dersi aldıktan sonra artık böyle bir durum ile karşılaştığımda hangi yolu, yöntemi izlemem gerektiğini biliyorum ve bunun bir öğretmen adayı için güzel bir şey olduğunu düşünüyorum.”

\section{İlk okuma Yazma Öğretimi dersinin Seçmeli ders grubunda olması ile ilgili görüşleriniz nelerdir? (Bu dersi öğretim üyesi Alan Seçmeli ders grubundan seçerek açmıştır.)}

Tablo 4. "İlk Okuma Yazma Öğretimi dersinin Seçmeli ders grubunda olması ile ilgili görüşleriniz nelerdir?” sorusuna yönelik katılımcı görüşleri

\begin{tabular}{|c|c|c|c|}
\hline \multirow[t]{3}{*}{ Kategoriler } & Kodlar & $\mathbf{f}$ & $\%$ \\
\hline & Zorunlu ders & 3 & 76,19 \\
\hline & $\begin{array}{rr} & \text { Adres } \\
\text { RumeliDE Dil ve Edebiyat Araşturmaları Dergisi } \\
\text { Osmanağa Mahallesi, Mürver Çiçeği Sokak, No:14/8 } \\
\text { Kadıöy - İSTANBUL / TÜRKIYY } 34714 \\
\text { e-posta: editor@rumelide.com } \\
\text { tel: }+90 \text { 505 7958124, +90 } 2167730616\end{array}$ & $\begin{array}{l}\text { Address } \\
\text { RumeliDE Journal o } \\
\text { Osmanağa Mahallesi } \\
\text { Kadıköy - ISTANBUl } \\
\text { e-mail: editor@rum } \\
\text { phone: +90 505 79? }\end{array}$ & $\begin{array}{l}\text { udies } \\
8\end{array}$ \\
\hline
\end{tabular}




\begin{tabular}{llll}
\hline \multirow{2}{*}{ Seçmeli ders } & Derse duyulan ihtiyaç & 25 & 59,52 \\
\cline { 2 - 4 } & Dersi görmeyen öğretmen adayları & 12 & 28,57 \\
\cline { 2 - 4 } & Türkçe öğretmeni yeterliliği & 9 & 21,42 \\
\cline { 2 - 4 } & Lisans müfredatı & 7 & 16,66 \\
\hline
\end{tabular}

Tablo 4'e göre öğretmen adayları, çoğunlukla bu dersin zorunlu ders olması gerektiğini ve derse duyulan ihtiyacı görüşlerinde belirtmişlerdir. Aynı zamanda dersi görmeyen öğretmen adaylarının ilk okuma yazma öğretimi konusunda yetersiz kalacaklarını, bu öğretimin Türkçe öğretmeninin sorumluluğunda olduğunu ve lisans müfredatında bu dersin zorunlu ders olması gerektiğini görüşlerinde ifade etmişlerdir:

Ö12: "illk okuma yazma dersi almayan öğretmen adayları bir, iki veya birçok öğrencisinin yani geleceğimizi böylesi önemli bir konuda bilgisiz brrakmamah. Dersimiz zorunlu olmalıdır.”

Ö33: “...Bence tüm Türkçe öğretmen adayları bu dersi almahdrr. Yani tüm üniversitelerde zorunlu bir ders olması daha iyi olabilir. Öğretim üyesinin inisiyatifine kalınca tüm Türkçe öğretmen adayları bu alanda eğitilmiş olmayacak ve öğretmenler arası farklar olacaktır."

Ö6: “...bu ders bence her öğretmen adayını alması gereken, ihtiyaç duyacağı bir ders. İleride öğretmen olduğumuzda öğrencinin okuma yazma bilmemesi durumunda ne yapabileceğimizi, bu eğitimi nasıl verebileceğimiz öğreten bir ders... Öğretmenlerimizin hiçbir durumda kendisini yetersiz hissetmemesi adına seçmeli olmaktan çıkarılıp zorunlu olması gereken bir ders olduğunu düşünüyorum. “

Ö13: "Bu dersin seçmeli bir ders olması bence bu dersi görmeyecek olan öğretmen adayları için, onların öğretmenlik mesleğine adım attıklarında karşılaşacakları sorunları düşündüğümde problemlere neden olacaktur."

Ö3: “İlk okuma yazma öğretimi dersi Türkçe öğretmenliği lisans programında zorunlu ders olarak yer almalı. Ortaokulda okuma-yazma bilmeyen öğrencilerin olması durumunda bu tüm öğretmenlerin sorunudur belki ama bir Matematik öğretmeninden ya da İngilizce öğretmeninden öğrencilere okuma-yazma eğitimi verilmesi beklenmez. Destek verilebilir, yardımcr olunabilir belki ama asıl öğretme Türkçe öğretmeni tarafindan yapılmah. Çünkü Türkçe öğretmeninin işlediği ders ve dil becerileri kapsamı Türkçe eğitimi alanında ve bu öğretimin Türkçe öğretmeni tarafindan yapılması daha uygun ve daha olumlu bir süreç oluşturur. Türkçe öğretmeni öğrencinin anlama, anlatma, dinleme, konuşma, okuma ve yazma becerileri konusunda en çok bilgi sahibi olan branş aym zamanda. Durum böyleyken Türkçe öğretmeni bu süreçte neler yapması gerektiğini bilmeli. Bunları öğrenmek için de bu dersi görmeli ve öğrenmeli.”

Ö38: "Bu dersin mutlaka zorunlu olması gerektiğini düşünüyorum... Ayrıca bu yıl katıldığımız okul deneyimi derslerinde 8.sinı öğrencilerinde bile ciddi anlamda okuma sıkıntısı çeken öğrenciler gördüm. Ben bu dersi aldım ve göreve başladiğımda bu sıkıntını üstesinden gelebilirim.”

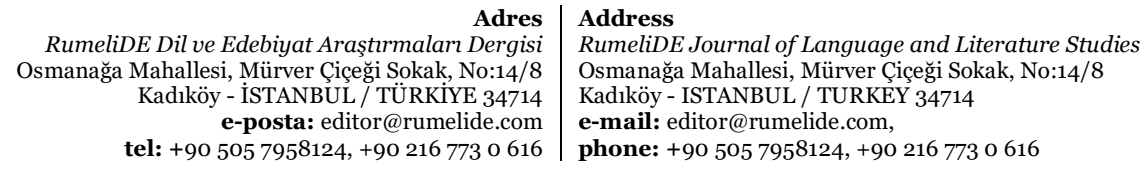




\section{İlk Okuma Yazma Öğretimi dersinde edindiğiniz bilgilerin öğretmenlik yaşamınıza katkı sağlayacağını düşünüyor musunuz? Açıklayınız.}

Tablo 5. "İlk Okuma Yazma Öğretimi dersinde edindiğiniz bilgilerin öğretmenlik yaşamınıza katkı sağlayacağını düşünüyor musunuz?” sorusuna yönelik katılımcı görüşleri

\begin{tabular}{llll}
\hline Kategoriler & Kodlar & $\mathbf{f}$ & $\mathbf{\%}$ \\
\hline & Farkında olma & 17 & 40,47 \\
\cline { 2 - 4 } Mesleğe katkıları & Hazır olma & 15 & 35,71 \\
\cline { 2 - 4 } & Çözüm üretme & 12 & 28,57 \\
\hline & $\begin{array}{l}\text { Öğrencilerin dil becerilerinin } \\
\text { geliştirilmesi }\end{array}$ & 11 & 26,19 \\
\hline & Fayda sağlama & 10 & 23,80 \\
\hline & Yardım etme & 10 & 23,80 \\
\hline & Yanlış öğrenmeleri düzeltme & 5 & 11,90 \\
\hline & Çevreye katkısı & 3 & 7,14 \\
\hline
\end{tabular}

Tablo 5 incelendiğinde öğretmen adayları İlk Okuma Yazma Öğretimi dersinin öğretmenlik mesleğine birçok katkısının olduğunu ifade etmişlerdir. Bu görüşlerden bazıları şöyledir:

Ö2: "Böyle bir dersi hiç almamış olsaydık okuma yazma öğrenmeden karşımıza çıkan ilk öğrenciye ne tepki vereceğimizi, nasıl öğreteceğimizi bilemezdik. Nasıl öğreteceğimizi öğrendik ve öğretmenlik hayatımızda karşımıza okuma yazma bilmeyen bir öğrenci çıtığında nasıl öğreteceğimizi, neyi öğreteceğimizi bildiğimiz için bilmeyene göre zaten daha donanıml ve hazırlıkl olacağız."

Ö3: "İlk okuma yazma öğretimi dersinin öğretmenlik yaşantımda kesinlikle çok büyük katkı sağlayacağım düşünüyorum. Bu ders sayesinde artık okuma-yazma bilmeyen öğrencilere bu öğretimin neden ve nasıl yapabileceğimi öğrendim. Böyle bir durumla karşılaştığımda hem vicdani hem de kuramsal anlamda ne yapmam gerektiğini artık çok iyi biliyorum."

Ö7: “...ilkokulda okuma yazma öğrenememiş öğrencilerim olursa onlara ne şekilde yaklaşmam gerektiğini ve nasıl bir eğitim vermem gerektiğini bu ders öncesinde bilmiyordum. Bu dersi aldıktan sonra, meslek hayatımda böyle bir öğrenciyle karşılaştığımda rahatlıkla ona yardım edebileceğimi düşünüyorum... Duruma nasıl yaklaşmam ve nasıl bir çözüm üretmem gerektiğini de yine bu ders sayesinde biliyorum. Öğretmenlik hayatımda, bu dersin bana yol göstereceğini düşünüyorum.”

Ö17: “Ayrıca yalnız meslek hayatımda değil, günlük yaşamımda da katkıları olacağı görüşündeyim. Çevremde okuma yazma sorunu yaşayan kişiler, öğrenciler gördüğümde onlara yardım edebileceğim."

Ö18: Öğretmenlik hayatıma katkı sağlayacağın düşünüyorum. Çünkü okuma yazma bilmeyen öğrenciler ile karşılaştı̆̆ımda nasıl bir yol izleyeceğim biliyorum. Öğrenci ile iletişime geçmem kolaylaşacak.

Ö25: “Öğretmenin amacı öğrencilere katkı sağlamaktır. Onların eksikliklerini tamamlamaktır. Bazen sıfirdan bilgi öğretmek bazen de yanlış bilgileri düzeltmektir. İlkokuldan ortaokula eksik gelen bir öğrenciye yapılabilecek en güzel katkı geçmişteki temel eksikleri tamamlamaktır.”

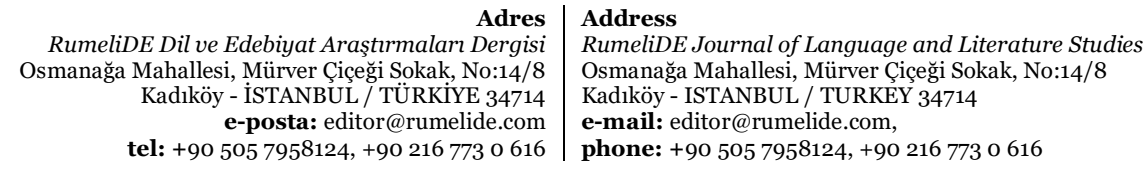




\section{İlk Okuma Yazma Öğretimi dersinin içeriğine yönelik önerileriniz nelerdir?}

Tablo 6. İlk Okuma Yazma Öğretimi dersinin içeriğine yönelik önerileriniz nelerdir?

\begin{tabular}{llll}
\hline Kategoriler & Kodlar & $\mathbf{f}$ & $\mathbf{\%}$ \\
\hline \multirow{3}{*}{ Öneriler } & Uygulama & 20 & 47,61 \\
\cline { 2 - 4 } & Güncellik & 10 & 23,80 \\
\cline { 2 - 4 } & Teknoloji kullanımı & 5 & 11,90 \\
\hline
\end{tabular}

Tablo 6'ya göre öğretmen adayları İlk Okuma Yazma Öğretimi dersine yönelik olarak uygulama, güncellik ve teknoloji kullanımı konusunda önerilerde bulunmuşlardır:

Ö15: "Öncelikli olarak bu dersin daha iyi anlaşılabilmesi için hitap edeceği kişilerin yani ilkokul öğrencilerine verilen okuma yazma eğitimi ve öğrencilerin eğitime verdiği tepkiler incelenmelidir. Bu inceleme işi zor gibi görünse de önceden kameraya kaydedilmiş örnek bir ders, Türkçe eğitimi lisans programındaki öğrencilere izletilerek daha çok verim alınılabilir.”

Ö14: "Genel anlamda uygulamah bir ders ama daha uygulamah hale getirilebilir. Örneğin bahsedilen sorunlarla karşılaşmış bir ortaokul öğretmeni derse konuk olarak getirilebilir ve öğrenciler ona sorular sorabilir."

Ö3:...”Dersin uygulama noktası için bu dersi alan öğrencilerin okullarda bu öğrencilere okuma-yazma öğretimi için destek vermelerini sağlama yoluna gidilebilir. Hem böylece öğretmenler bunu gerçek bir ortamda uygulayarak tecrübe edebilirler."

Ö11: “...İ̧crik ile güncellenmiş materyallerinin birleştirilmesiyle dikkat süreli sinırh olan öğrencilerin derse güdülenmesi ve odaklanması daha kolay olacaktır. Bu nedenle öğrenme ortamlarının artık simıf ile sinırl kalmayıp üç boyutlu dijital ortamlara taşınarak içeriğin de çă̆a uygun öğrenmelerle güncellenerek kazandırılması gerektiğini düşünüyorum.”

\section{Tartışma, sonuç ve öneriler}

İlkokul, temel eğitimin başlangıcıdır. Bu yıllarda insan hayatını etkileyen bilgi ve beceriler edinilir. 4 yıl süren bu eğitim ilk okuma yazma ve temel matematik becerileri kazandırmakla başlar. Ancak bu dönemde çeşitli sebeplerle kazanılamayan beceriler ilerleyen yıllara taşınır. Ortaokul öğrencilerinin okuma ve yazma becerilerinde yaşadıkları sorunlar üzerine yapılan araştırmalarda da ilkokulda tamamlanması gereken becerilerin ortaokulda dâhi tamamlanmadığını ve bu nedenle öğrencilerin okuma ve yazma becerilerinin istenilen düzeyde olmadığı ortaya konmuştur. Bu durum, öğrencinin gerek akademik başarısına gerekse günlük hayatına olumsuz etki etmektedir (Bilge ve Sağır, 2017; Bahşi ve Sis, 2019).

Bu çalışmada, Türkçe öğretmeni adaylarının İlk Okuma Yazma Öğretimi dersine yönelik görüşleri belirlenmiştir. Çalışma sonucunda öğretmen adaylarının İlk Okuma Yazma Öğretimi dersini Temel eğitim, Ses esash ilk okuma yazma ve Hayatilik kodlarıyla tanımladıkları görülmektedir. Öğretmen adaylarının yaptıkları tanımlar neticesinde ortaya çıkan kodlar İlk Okuma Yazma Öğretimi dersinin eğitimin temeli olduğunu ve hayati bir önem taşıdığını göstermektedir. İlk okuma yazma öğretiminin bu önemi insan hayatını etkileyen bir ders olmasından ileri gelir.

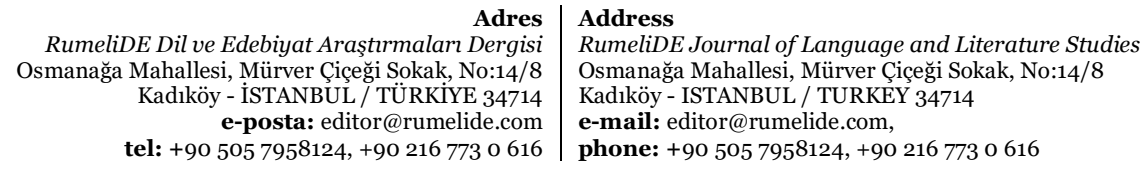


Türkçe öğretmeni adayları, İlk Okuma Yazma Öğretimi dersini almadan önce bu derse yönelik olarak Ön yargı, Alana uygunluk, Merak ve Belirsizlik kodlarını ortaya çıkaran görüşler belirtmişlerdir. Bu durum, öğretmen adaylarının İlk Okuma Yazma Öğretimi dersine olan ihtiyacı henüz kavrayamadıklarından kaynaklanmaktadır. Öğretmen adayları dersi aldıktan sonra bakış açılarında önemli bir değişim meydana geldiğini belirtmişlerdir. Dersin gerekliliğine, önemine, öğrenciye katkısına vurgu yapan öğretmen adayları ortaokul yıllarında da okuma-yazma bilmeyen akranları olduğunu hatırlayıp derse yönelik bakış açılarını olumlu yönde değiştirdiklerini ifade etmişlerdir.

Öğretmen adaylarının ortaokulda okuma ve yazma bilmeyen akranları olduğuna ya da öğretmen olduklarında okuma-yazma bilmeyen öğrencileri olabileceğine ilişkin görüşleri araştırmalarda da ortaya konmuştur. Yapılan araştırmalar ilkokul düzeyinde okuma ve yazma konusunda sorun yaşayan öğrencilerin bu sorunlarını ortaokula ve liseye kadar taşıdıklarını ortaya koymaktadır (Başar, 2013; Tok ve Ünlü, 2014; Bilge ve Sağır, 2017).

Çalışmada İlk Okuma Yazma Öğretimi dersinin seçmeli ders grubunda olması ile ilgili olarak alınan görüşler nitecesinde öğretmen adaylarının bu dersin zorunlu ders olması gerektiğini vurguladıkları görülmektedir. Lisans müfredat programında seçmeli ders olması sebebiyle bu dersi almayan öğretmen adaylarının ilk okuma yazma öğretiminin ilkelerini bilmemekten kaynaklanan bir yetersizlik yaşayacakalarını da belirtmişlerdir.

İlk Okuma Yazma Öğretimi dersinde edinilen bilgilerin öğretmenlik yaşamına sağlayacağı katkıları Farkında olma, Hazır olma, Çözüm üretme, Öğrencilerin dil becerilerinin geliştirilmesi, Fayda sağlama, Yardım etme, Yanlş öğrenmeleri düzeltme, Çevreye katkısı olmak üzere birçok kodda dile getirmişlerdir. Bu sonuç, öğretmen adaylarının İlk Okuma Yazma Öğretimi dersini aldıktan sonra derse duyulan ihtiyaç noktasında görüşlerini geliştirdiklerini ortaya koymaktadır. Öğretmen adayları dersin içeriğine yönelik olarak ise Uygulama, Güncellik ve Teknoloji kullanımı hususlarında önerilerde bulunmuşlarıdır.

Çalışma sonucunda Alan Eğitimi Seçmeli Ders grubunda yer alan İlk Okuma Yazma Öğretimi dersinin lisans müfredatında zorunlu ders grubunda olması gerektiği öğretmen adaylarının görüşlerinden hareketle ortaya çıkmıştır. İlk Okuma Yazma Öğretimi dersine duyulan ihtiyaç öğretmen adayları tarafından vurgulanmıştır. Dersi alan öğretmen adayları meslek hayatlarında okuma ve yazma bilmeyen öğrenciyle karşılaştıklarında aldıkları eğitim sayesinde bu durumun üstesinden gelebileceklerini belirtmişlerdir.

Çalışmada ortaya çıkan bu sonuçlar neticesinde Türkçe öğretmeni adaylarının mesleğe başlamadan karşılaşacakları zorlukları tanımaları ve bu duruma hazır olmaları gerektiği düşünülmektedir. Türkçe öğretmenlerinin yaşayacakları birçok sorunun yanında okuma yazma bilmeyen öğrencilerinin olması karşılaşlan zorlukların başında gelir. Öyle ki, okuma ve yazma bilmeyen bir öğrenci gerek Türkçe dersinde gerek diğer derslerde başarılı olamaz. Hatta bu beceriyi kazanamamış öğrenci sosyal hayatında da önemli sorunlar yaşar. Bu noktada önemli olan Türkçe öğretmeninin karşısına çıkan bu zorlukla mücadele etme yöntemlerini bilmesidir. Türkçe öğretmeninin öğretmen adayı olarak aldığı eğitimöğretim süresince bu yöntemleri öğrenmesi onu mesleğe hazırlayan önemli adımlardan biridir. Bu nedenle Türkçe öğretmenliği lisans müfredatında İlk Okuma Yazma Öğretimi dersinin zorunlu ders olarak okutulmasında fayda görülmektedir.

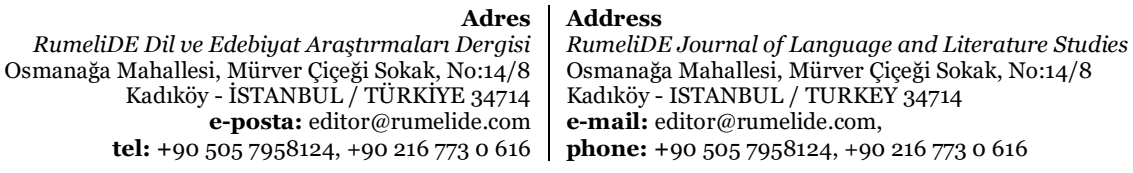




\section{Kaynakça}

Babayiğit, Ö. ve Erkuş, B. (2017). İlk okuma yazma öğretimi sürecinde sorunlar ve çözüm önerileri. Erzincan Üniversitesi Eğitim Fakültesi Dergisi, 19(2), 271-284.

Bahşi, N. ve Sis, N. (2019). Ortaokul öğrencilerinin yazma düzeyleri ve yazılarında karşılaşılan sorunlar. Millî Eğitim, 48(224), 181-211.

Başar, M. (2013). Okuma yazma öğrenerek ilkokula başlayan çocukların karşılaştıkları sorunların değerlendirilmesi. Ekev Akademi Dergisi, Sayı: 1 275-294.

Başar, M. ve Gürbüz, H. M. (2020). İlk okuma ve yazma öğretiminde karşılaşllan sorunlar ve çözüm önerileri. Okuma Yazma Eğitimi Araştırmaları, 8(1), 1-20.

Bilge, H. ve Sağır, M. (2017). Ortaokul öğrencilerinin okuma hatalarının çeşitli değişkenlere göre incelenmesi. Ihlara Eğitim Araştırmaları Dergisi, 77-88 2(1).

Creswell, J. W. (2021). Nitel araştırma yöntemleri beş yaklaşıma göre nitel araştırma ve araştırma deseni (Çev. Ed. Selçuk Beşir Demir, Mesut Bütün). Ankara: Siyasal Yayın Dağıtım.

Çetinkaya, S. (2021). Sınıf öğretmenleri anlatıyor: ilkokuma yazma öğretimi. Ondokuz Mayıs Üniversitesi Eğitim Fakültesi Dergisi, 40(1) 80-106.

Göçer, A. (2019). Etkinlik temelli ilkokuma ve yazma öğretimi. Ankara: Pegem Akademi.

Gönül, İ. ve Arslan, R. (2018). Birleştirilmiş sınıftan mezun öğrencilerin üst eğitim kademesinde karşılaştıkları sorunlar. Amasya Üniversitesi Eğitim Fakültesi Dergisi, 7(1), 43-62.

Güneş, F. (2019). İlkokuma yazma öğretimi yaklaşımlar ve modeller. Ankara: Pegem Akademi.

Karayel, E. (2017). Birleştirilmiş Sınıf uygulaması olan ilkokullarda görevli öğretmenlerin yaşadığı sorunlar. International Journal Of Leadership Training, 1(1), 26-39.

Millı̂ Eğitim Bakanlığı, (2019). Türkçe dersi öğretim programı (ilkokul ve ortaokul 1, 2, 3, 4, 5, 6, 7 ve 8. Sinıflar). Ankara: Devlet Kitapları Basım Müdürlüğü.

Tok, M. ve Ünlü, S. (2014). Yazma becerisi sorunlarının ilkokul, ortaokul ve lise öğretmenlerinin görüşleri doğrultusunda karşılaştırılmalı olarak değerlendirilmesi. Elektronik Sosyal Bilimler Dergisi, 13(50), 73-95.

Yıldırım, A. ve Şimşek, H. (2018). Sosyal bilimlerde nitel araştırma yöntemleri. Ankara: Seçkin.

Yüksek Öğretim Kurulu (2018). Öğretmen yetiştirme lisans programları. [Online]: https://www.yok.gov.tr/Documents/Kurumsal/egitim_ogretim_dairesi/Yeni-OgretmenYetistirme-Lisans-Programlari/Turkce_Ogretmenligi_Lisans_Programi.pdf Erişim Tarihi: 13. 09. 2021.

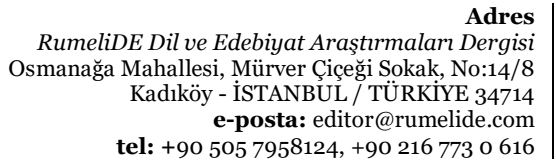

dres

RumeliDE Journal of Language and Literature Studies

Osmanağa Mahallesi, Mürver Çiçeği Sokak, No:14/8

Kadıköy - ISTANBUL / TURKEY 34714

e-mail: editor@rumelide.com,

phone: +90 5057958124 , +90 2167730616 